\title{
Inhibition of Lipid Oxidation by MRP Antioxidant in Enriched Cooked Beef Patties with Polyunsaturated Fatty Acids
}

\author{
Carina Lorena Fernandez ${ }^{1,2}$, Mario Anibal Sturla ${ }^{1}$, Mirtha Marina Doval ${ }^{1}$, Ana Maria Romero ${ }^{1}$ \\ \& Maria Alicia Judis ${ }^{1}$ \\ ${ }^{1}$ Laboratory of Food Industry, Chaco Austral National University, Comandante Fernandez, Chaco, Argentina \\ ${ }^{2}$ CONICET (Consejo Nacional de Investigaciones Cientificas y Tecnicas) \\ Correspondence: Carina Lorena Fernandez, Laboratory of Food Industry, Chaco Austral National University, \\ Comandante Fernandez 755, Chaco, Argentina. Tel: 54-036-4442-0137. E-mail: carina@uncaus.edu.ar
}

Received: May 8, 2012 Accepted: May 31, 2012 Online Published: July 2, 2012

doi:10.5539/jfr.v1n3p128 URL: http://dx.doi.org/10.5539/jfr.v1n3p128

The research is financed by Chaco Austral National University and CONICET and conducted at Food Industry Laboratory at Chaco Austral University

\begin{abstract}
The addition of $\mathrm{n} 3$ polyunsaturated fatty acids to foods is an emerging area of commercial and academic interest. However, the incorporation of $\mathrm{n} 3$ polyunsaturated fatty acids into food systems is potentially problematic due to their propensity to oxidize easily. The antioxidant capacity of MRP has mostly been studied in vitro, in fresh chicken, mutton and pork, and in precooked ground pork and beef patties and sausages. The aim of this study is to evaluate the antioxidant properties as well as the antioxidant effect of a preformed Maillard Reaction Product (MRP) from sarcoplasmic proteins/malondialdehyde, known for its antioxidant effect on water/oil emulsion and on lipid oxidation of beef patties when the level of n3 PUFA is improved. The MRP presented a high reducing power, a low phenolic compound content (9.2 mg gallic acid equivalent/g and $798.3 \mathrm{mg}$ quercetin equivalent/g), and a minor DPPH and ABTS+ radicals scavenging activity (34\% and 23,5\%, respectively). All concentrations of MRP assayed inhibited hydroperoxide formation and thiobarbituric acid reactive substances (TBARS) production during refrigerated storage of enriched meat patties. The $3 \%$ concentration was the most efficient and exerted an $83 \%$ and $85 \%$ inhibition of peroxidation measured as peroxide value and TBARS, respectively.
\end{abstract}

Keywords: maillard reaction, reducing power, DPPH, ABTS, meat, sarcoplasmic proteins, malondialdehyde, peroxide value

\section{Introduction}

Lipid oxidation is common in many foods and results in loss of functional, sensory, and nutritional quality. Antioxidants, whether naturally present or added to foods, retard but may not completely inhibit lipid oxidation. Meat industry is decreasing its use of artificial antioxidants, such as BHT, BHA and TBHQ (Naveena, Sen, Kingsly, Singh \& Kondaiah, 2008), therefore there is an increasing interest in using natural antioxidants, such as grape pomace, plum, almond skins and Maillard reaction products (Vasavada \& Cornforth, 2006).

The nonenzymatic Maillard Reaction Products (MRPs) formed during processing, packaging and storage via amino and carbonyl compound interactions are common in many food systems. Several studies have demonstrated that MRPs can act as radical scavengers and as metal chelators (Gomyo \& Hirokoshi, 1976; Johnson, Metcalf \& Baker, 1983; Rendleman, 1987; Asakura, Nakamura, Inou, Murata \& Homma, 1990; Terasawa, Murata \& Homma, 1991), thus potentially providing more than one mechanism of action in preventing the lipid oxidation. Since MRPs are naturally synthesized during many food processes, (Lingert \& Eriksson, 1981), the antioxidant character associated with MRPs may be considered as a value-added component.

Many studies have focused on extending the shelf life of heated processed foods by incorporating the primary reactants of Maillard reaction (e.g. amino acids and reducing sugars) before the processing (Bedinghans \& Ockerman, 1995), or alternatively, some other studies have been directed towards adding preformed MRPs to food to provide an antioxidant activity (Lingert \& Eriksson, 1981). There are reports about the use of preformed 
MRPs as antioxidants in cooked meats from different species (Bedinghans \& Ockerman, 1995; Jayathilakan, Vasundhara \& Kumudavally, 1997).

Cooked meat is susceptible to lipid oxidation, and phospholipids are the primary contributors to lipid oxidation and WOF development (Gandemer, 1999; Mottram, 1991; Pearson \& Gray, 1983).

On the other hand, bovine fat is rich in saturated fatty acids, particularly palmitic acid, which is considered a hypercholesterolemic fatty acid (Decker \& Shantha, 1994); therefore it would be required to improve the nutritional value of the fat increasing the polyunsaturated fatty acid (PUFA) level (Elmore, Mottram, Enser, \& Wood, 1999; Eweedah, Rozsa, Gundel, \& Varlegyi, 1997). The addition of n3 polyunsaturated fatty acids to foods is an emerging area of commercial and academic interest. Previous researchers have shown that it is possible to incorporate n3 PUFA into various food systems (Jafar, Hultin, Bombo, Crowther, \& Barlow, 1994; Jacobsen et al., 2001); however, the incorporation of $\mathrm{n} 3$ polyunsaturated fatty acids is potentially problematic due to their propensity to oxidize easily.

The hamburger patty represents the world's most popular processed meat product, probably because of convenience and price (Hoogenkamp, 1997). Due to high consumption, the factors that affect quality of patties acquire high relevance. As patties remarkably contain more fat than sheer muscle, they are very susceptible to oxidation during mincing and cooking. Besides, the addition of salt promotes the formation of reactive oxygen species and hence, the occurrence and intensity of the oxidative reactions are increased (Ladikos \& Lougovois, 1990).

In a previous study, it has been reported that lipid profile of patties was improved by using soybean oil to partially replace the fat used in the formulation, although it increased susceptibility to lipid oxidation (Romero, Doval, Sturla, \& Judis, 2010).

The aim of this study is to evaluate the antioxidant properties as well as the antioxidant effect of a preformed MRP on lipid oxidation of beef patties when the level of n3 PUFA is increased.

\section{Materials and Methods}

\subsection{Preparation of Maillard Reaction Products}

MRPs were obtained from sarcoplasmic proteins and malondialdehyde (MAD) reaction. Sarcoplasmic proteins were extracted from 20g local market beef, according to Wagner and Añón (1985) procedure. These proteins were suspended in phosphate buffer, $\mathrm{pH}=7.6$ and their concentration was determined by a modified Biuret method (Robson, Goll, \& Temple, 1968). MAD was prepared from an acid hydrolysis of $10 \mu 1$ 1,1,3,3-tetramethoxypropane (TMP) according to Kakuda, Stanley and Van de Voort (1981), the stock solution was adjusted to $\mathrm{pH}=7.6$ and their concentration was quantified by absorbance at $245 \mathrm{~nm}$ using $\varepsilon=13700 \mathrm{M}^{-1}$ $\mathrm{cm}^{-1}$. Sarcoplasmic proteins were incubated with MDA in a ratio 3.5:1 and heated at $80{ }^{\circ} \mathrm{C}$ for $4 \mathrm{~h}$ (under moderated agitation) to obtain an early Maillard-like reaction product. The reaction mixture was dried under vacuum (at $50^{\circ} \mathrm{C}$ and $4000 \mathrm{~Pa}$ ) to get a dry extract. Various concentrations were used to evaluate the antioxidant properties

\subsection{Reducing Power Determination}

The reducing power of MRPs was determined according to Oyaizu method (1986); 0.5 to $8 \mathrm{mg}$ of MRPs were dissolved in $1 \mathrm{ml}$ of $0.2 \mathrm{M}$ of sodium phosphate buffer ( $\mathrm{pH}$ 6.6) and mixed with $1 \mathrm{ml}$ of $1 \%$ potassium ferricyanide $\left(\mathrm{K}_{3} \mathrm{Fe}\left(\mathrm{CN}_{6}\right)\right)$. The reaction mixture was incubated in a temperature - controlled water bath at $50^{\circ} \mathrm{C}$ for 20 minutes, followed by the addition of $1 \mathrm{ml}$ of $10 \%$ trichloroacetic acid. The mixture was then centrifuged at $650 \mathrm{rpm}$ for 10 minutes. The supernatant obtained $(1 \mathrm{ml})$ was treated with $1 \mathrm{ml}$ distilled water and $200 \mu \mathrm{l}$ of $0.1 \% \mathrm{FeCl}_{3}$. The absorbance of the reaction mixture was measured at $700 \mathrm{~nm}$ in a UV-visible Beckman DU 640B, Fullerton, CA, USA spectrophotometer. An increase in the absorbance was used as the measure for reducing power. Higher absorbance indicated a higher reducing power.

\subsection{Scavenging Effect on DPPH and ABTS Radicals}

1, 1-diphenyl-2-picrylhydrazyl radical scavenging activity of dry extract $(0.5$ to $8 \mathrm{mg} / \mathrm{ml}$ ethanol $)$ was determined in an ethanolic DPPH solution $(0.12 \mathrm{mM}$, Sigma-Aldrich). The absorbance of DPPH was spectrophotometrically monitored at $517 \mathrm{~nm}$. A $3 \mathrm{ml}$ ethanolic solution of DPPH was added to $100 \mu \mathrm{l}$ of the antioxidant solution. The decrease of the absorbance was read for ten minutes, using ethanol as blank and DPPH solution as control.

The radical scavenging activity by the 2, 2'-azino-bis (3-ethylbenzthiazoline-6-sulphonic acid) radical cation discoloration assay was measured as described by Re et al. (1999). The bleaching rate of $\mathrm{ABTS}^{+}$in the presence 
of the sample was spectrophotometrically monitored at $734 \mathrm{~nm}$. The reaction was started by adding $100 \mu 1$ of an antioxidant solution (containing 0.5 to $8 \mathrm{mg} \mathrm{MRP} / \mathrm{ml}$ ethanol). $\mathrm{ABTS}^{+}$bleaching was monitored at $25^{\circ} \mathrm{C}$ for at least $30 \mathrm{~min}$ and the discoloration after $10 \mathrm{~min}$ was used as the measure of antioxidant activity. The inhibition percentage of free radicals DPPH and ABTS (I \%) was calculated using equation 1:

$$
I \%=\frac{\left(A_{\text {blank }}-A_{\text {sample }}\right)}{A_{\text {blank }}} \times 100 \%
$$

Also, radical scavenging activities for both determinations were expressed as mg of Vitamin C equivalent per g of sample by means of the dose - response curve for Vitamin C.

\subsection{Total Phenolic Compounds Determination}

Total phenolics content was determined using Folin-Ciocalteau (FC) reagent and a colorimetric assay based complex formation of phenolics with $\mathrm{AlCl}_{3}$ (Kalogeropoulos, Yannakopoulou, Gioxari, Chiou, \& Makris, 2010). For phenolics determination with FC, analytical grade gallic acid was used as standard. A $5 \mathrm{mg} / \mathrm{ml} \mathrm{MRP} \mathrm{solution}$ $(1 \mathrm{ml})$ or a standard solution $(1 \mathrm{ml})$ was added to $10 \mathrm{ml}$ deionised water and $2.0 \mathrm{ml}$ Folin-Ciocalteau phenol reagent (Merck, Darmstadt, Germany). The mixture was then allowed to stand for 5 minutes and $2.0 \mathrm{ml}$ of sodium carbonate (saturated solution) were added. After 1 hour in darkness, the absorbance at $735 \mathrm{~nm}$ was measured. The concentration of total phenolics was expressed as $\mathrm{mg}$ of gallic acid equivalent per $\mathrm{g}$ of dry extract by using an equation that was obtained from a standard gallic acid graph $\left(\mathrm{R}^{2} 0.995\right)$. For phenolic determination using an aluminum colorimetric assay, $1 \mathrm{ml}$ of appropriate ethanolic MRP dilution $(5 \mathrm{mg} / \mathrm{ml})$ was added to $4 \mathrm{ml}$ of distilled water. At time zero, $0.3 \mathrm{ml}$ of $5 \% \mathrm{NaNO}_{2}$ was added. Ten percent of $\mathrm{AlCl}_{3}(0.3 \mathrm{ml})$ was added $5 \mathrm{~min}$ later. At $6 \mathrm{~min}, 2 \mathrm{ml}$ of $1 \mathrm{M} \mathrm{NaOH}$ were added and the solution was made up to $10 \mathrm{ml}$ with distilled water and then mixed. The absorbance was measured at $510 \mathrm{~nm}$ against an appropriate blank. Total phenolics were expressed as milligrams of quercetin equivalent per g of dry extract. Quercetin solutions (10 to $500 \mathrm{mg} / \mathrm{L})$ were used as standards.

\subsection{Preparation of Meat Patties}

Beef patties were prepared with $800 \mathrm{~g}$ meat, $200 \mathrm{~g}$ porcine fat and $20 \mathrm{~g}$ sodium chloride. In order to introduce $\mathrm{n} 3$ PUFA, the same formulation was used, replacing $100 \mathrm{~g}$ of porcine fat by $100 \mathrm{~g}$ of soybean oil. Different MRP concentrations $(0 \%, 0.5 \%, 1 \%, 2 \%, 3 \%$ and $5 \%)$ were added, and BHA $(0.01 \% \mathrm{w} / \mathrm{w})$ was used as control.

All ingredients were minced and mixed; the patties were formed $(50 \pm 1 \mathrm{~g})$ in pieces of $5 \mathrm{~cm}$ diameter and $1 \mathrm{~cm}$ thickness. Then, all samples were placed in trays and cooked at $100^{\circ} \mathrm{C}$ for 1 hour in conventional oven, until a meat core temperature of $73^{\circ} \mathrm{C}$ was achieved. All cooked patties were packed in polypropylene bags and kept at $8^{\circ} \mathrm{C}$ for evaluation at 8 and 15 days. The course of oxidation was monitored by measuring peroxide value (PV) and thiobarbituric acid reactive substances (TBARS).

The antioxidant activity at the end of the assay time was expressed for each indicator as reduction percent of peroxidation (RP \%), with a control without antioxidant:

$$
\mathrm{RP} \%=\frac{\left(\text { Peroxidation indicator value }_{\text {blank }}\right)-\left(\text { Peroxidation indicator value }_{\text {sample }}\right)}{\left(\text { Peroxidation indicator value }_{\text {blank }}\right)} \times 100 \%
$$

A higher percentage indicated a higher antioxidant activity.

\subsection{Fat Extraction}

The Bligh and Dyer method (1959) was used for fat extraction from samples. The extraction procedure is briefly as follows: $4.5 \mathrm{ml}$ of chloroform were added to a $10 \mathrm{~g}$ sample followed by the addition of $10 \mathrm{ml}$ of methanol, and $10 \mu \mathrm{l}$ of $0.01 \%$ BHA ethanolic solution, and mixed for 3 minutes; then $6.5 \mathrm{ml}$ of distilled water and $4.5 \mathrm{ml}$ chloroform were added. After decantation, the organic phase was isolated. This extract was collected in cap tubes, which were heated in water bath $\left(50^{\circ} \mathrm{C}\right)$ and kept under nitrogenous flow. After chloroform evaporation, cap tubes were kept at $-20^{\circ} \mathrm{C}$ until further analysis.

\subsection{Peroxide Values}

The FTC (ferric thiocyanate) method was adapted from the FIL-IDF method 74A:1991. A $0.02 \mathrm{~g}$ of samples dissolved in $9.8 \mathrm{ml}$ methanol: chloroform (70:30) solution and $0.1 \mathrm{ml}$ of $30 \%(\mathrm{w} / \mathrm{v})$ ammonium thiocyanate were added and mixed. Precisely 5 min after the addition of $0.1 \mathrm{ml}$ of ferrous chloride in $3.5 \% \mathrm{v} / \mathrm{v}$ hydrochloride acid to the reaction mixture, the absorbance of the resulting red color was measured at $501 \mathrm{~nm}$ 
against solvent solution as blank. Peroxide values were expressed in terms of mmoles of oxygen per $\mathrm{kg}$ of sample.

\subsection{Thiobarbituric Acid-reactive Substances (TBARs)}

Lipid oxidation was evaluated by TBARs according to Sinnhuber and Yu (1997) with slight modifications. A sample $(100 \mu \mathrm{g})$ was placed in $10 \mathrm{ml}$ test tubes; then $10 \mu \mathrm{l}$ of antioxidant solution (BHA, $0.01 \%$ ) and $2 \mathrm{ml}$ of TBA solution (20mM TBA in $15 \%$ TCA) were subsequently added. The mixture was vortexed and heated in water bath $\left(90^{\circ} \mathrm{C}\right)$ for 15 minutes. After cooling at room temperature, $2 \mathrm{ml}$ of chloroform were added, followed by centrifugation at $2000 \mathrm{rpm}$ for 15 minutes. The absorbance of supernatant was read at $532 \mathrm{~nm}$ against a blank containing $0.1 \mathrm{ml}$ of distilled water and $2 \mathrm{ml}$ of TBA/TCA solution. Malondialdehyde standard curve was prepared from different 1, 1, 3, 3-tetramethoxypropane solutions, and TBARS were expressed as $\mathrm{mg}$ of malondialdehyde $/ \mathrm{kg}$ dry matter.

\subsection{Fatty Acid Profile}

A Boron trifluoride/methanol solution was used for fatty acid methyl esters preparation according to AOAC $\mathrm{N}^{\circ}$ 969.33. Fatty acid composition was determined by using a HP 6850 Gas chromatograph equipped with a Supelco 2340 capillary column ( $50 \mathrm{~m}$ length, $0.25 \mu \mathrm{m}$ internal diameter) and a FID detector. Standard methyl esters of fatty acids of $99 \%$ purity (Sigma-Aldrich) were used. The fatty acids composition from patties was obtained by comparing the relative retention times of standards. The injector and detector temperature were $260{ }^{\circ} \mathrm{C}$; the oven temperature was held at $120^{\circ} \mathrm{C}$ for $2 \mathrm{~min}$ and subsequently increased at $4{ }^{\circ} \mathrm{C} / \mathrm{min}$ to $240^{\circ} \mathrm{C}$.

\section{Results and Discussion}

\subsection{Reducing Power}

Reducing power of MRPs increased with the increase of MRPs concentrations. It reached 0.313 of absorbance at $700 \mathrm{~nm}$ with a concentration of $0.5 \mathrm{mg} / \mathrm{ml}$, and increased to 0.725 of absorbance with a concentration of 8 $\mathrm{mg} / \mathrm{ml}$.These results revealed that MRPs could function as good electron donors, even better than BHA (0.1 $\mathrm{mg} / \mathrm{ml}$ ), whose absorbance was only 0.431 . These results are in agreement with the previous reports of Ajandouz, Desseaux, Tazi and Puigserver (2008), who described that intermediate compounds of MRPs, such as reductones formed during heating, may act break the free radical chain reactions by donation of a hydrogen atom (Benjakul, Lertittikul, \& Bauer, 2005).

Furthermore, a high reactivity was noted at the lowest MRPs concentration, while at higher concentrations, though an RP increase with concentration was observed, such increase was not proportional, probably indicating saturation of the reactive sites of the reductones or interference reactions.

\subsection{DPPH and ABTS Radical Scavenging Activity}

Concentrations of $0.5,1,2,4$ and $8 \mathrm{mg} / \mathrm{ml}$ of MRPs were used for both assays.

The highest free radical activity inhibition (34\%) was obtained with the lowest MRPs concentration tested $(0.5$ $\mathrm{mg} / \mathrm{ml})$, as shown in Figure 1. Although the MRP showed the same behaviour that the control $(0.1 \mathrm{mg} / \mathrm{ml} \mathrm{of}$ BHA), its effect was less pronounced. I\% of BHA was $96 \%$.

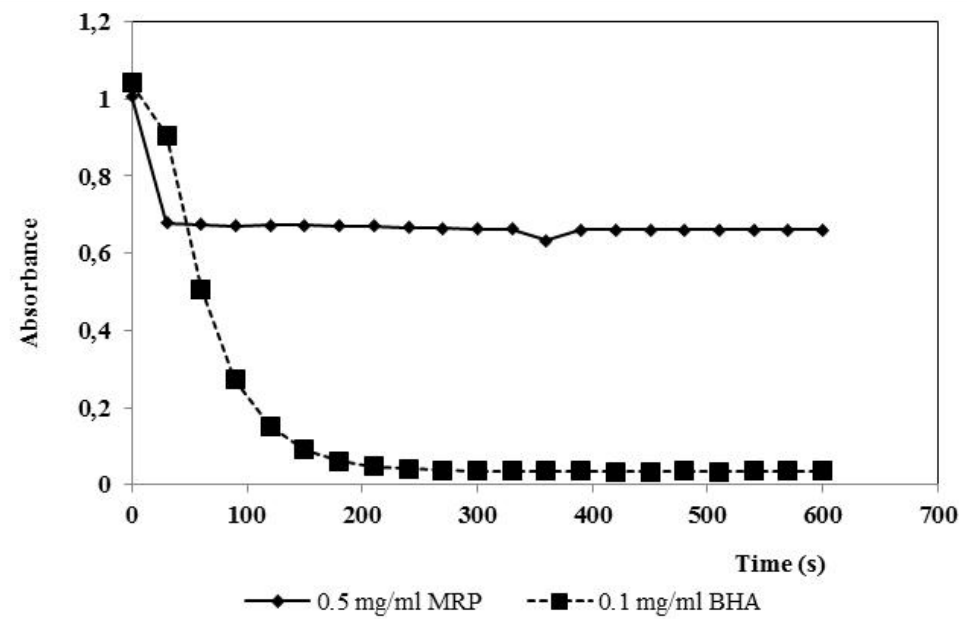

Figure 1. DPPH scavenging activity of MRP and BHA 
An increase of scavenging activity with increasing concentration could not be observed, probably due to interfering reactions, since it has been demonstrated that hydrophobic radicals are unable to attack macromolecules (such as MRPs derived from proteins) in solution (Dean, Hunt, Grant, Yamamoto, \& Niki, 1991). Therefore, it is unlikely that DPPH, a relatively hydrophobic radical, could interact with MRPs to a sufficient extent when organic solvents, as ethanol, are used for these assays.

These results are in agreement with Gu et al. (2009), who reported that MRPs from casein glucose showed a scavenging activity of $28 \%$ for $0.5 \mathrm{mg} / \mathrm{ml}$, and also a lower activity of MRPs compared to the synthetic antioxidant used as positive control.

On the other hand, the inhibition percent of free radicals exerted by the MRPS resulting from this assay was higher than that informed by Jing and Kitts (2002) for MRPs from Ribose-Casein (3-7\%) at similar concentrations.

Unlike hydrophobic radicals, hydrophilic radicals, such as ABTS, can interact to a larger extent with MRPs in aqueous solution (Rival, Boeriu, \& Wichers, 2001); hence all MRPs concentrations could be assayed. The reduction of ABTS radicals was evaluated by monitoring the decrease in its absorbance during the reaction with MRPs.

Figure 2 shows the dependence of MRPs concentration on scavenging activity of ABTS radicals. For the highest concentration of MRPs ( $8 \mathrm{mg} / \mathrm{ml}$ ) I\% was 23.5 , lower than that reported by Sun et al. (2006) who informed an inhibition of $30 \%$ at the same concentration of MRPs obtained from ovalbumin and glucose.

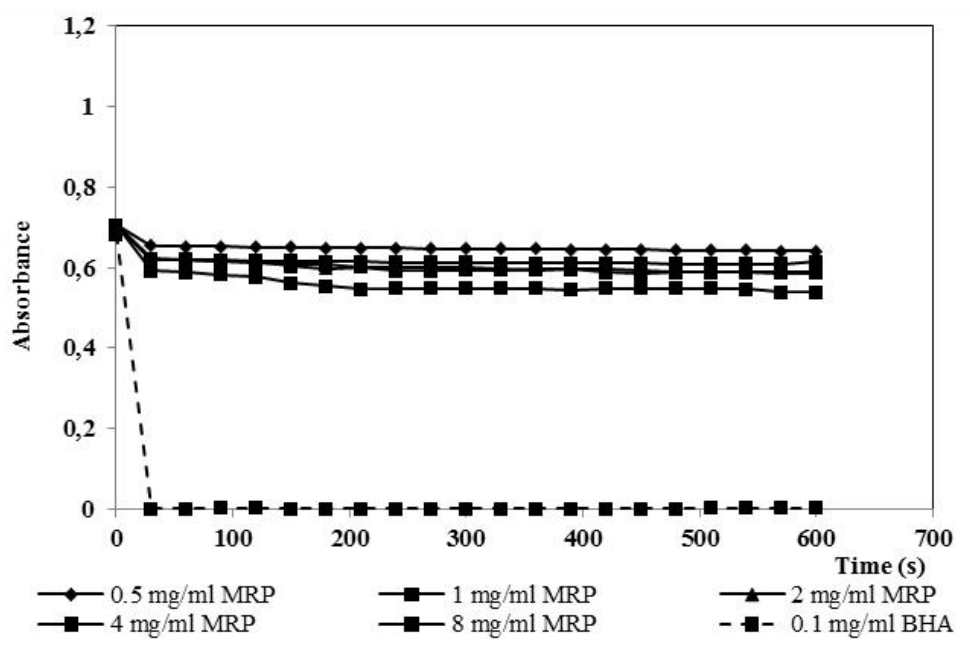

Figure 2. ABTS scavenging activity of different MRP concentrations and BHA

\subsection{Total phenolic Compounds}

The results showed that total phenolic compounds were $9.2 \mathrm{mg}$ acid gallic equivalent/g MRPs and $39.70 \mathrm{mg}$ quercetin equivalent/g MRPs. When testing antioxidant activity of positive control, $798.3 \mathrm{mg}$ gallic acid equivalent/g BHA and $139.54 \mathrm{mg}$ quercetin/g BHA were found. It is known that both phenolic and flavonoid components are commonly present in vegetables and fruits, thus they are impossible to be found in MRPs. However, the activity levels detected could be due to a generated structure during MRP formation, since it is also known that Maillard reaction and caramelization are two important pathways to produce phenolic pigments (melanoidins) (Powrie, Wu, \& Mohund, 1986; Maydata, 2002).

\subsection{Oxidative Stability}

The partial replacement of porcine fat by soybean oil increased n3 PUFA of short chain content from $1.70 \%$ to $3.65 \%$ and n6 PUFA from $12 \%$ to $28 \%$ (Figure 3). The relation PUFA/SFA increased three times approximately, and the $n-6 / n-3$ ratio remained between 6.5 and 7 . These results indicated that fatty acid composition changed and also that modified patties were healthier due to the higher contents of unsaturated and essential fatty acids. 

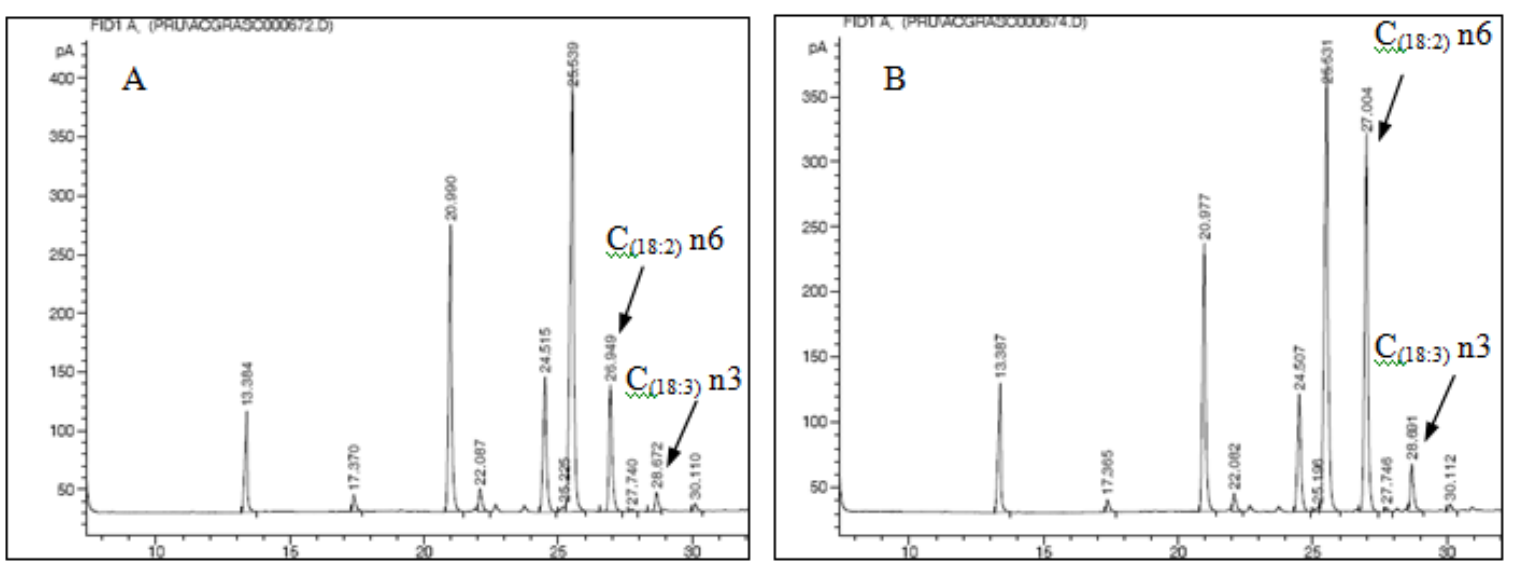

Figure 3. Fatty acid composition of meat patties. A) without soybean oil and B) with soybean oil

Lipid oxidation is a complex process in which unsaturated fatty acids react with molecular oxygen, usually via a free radical mechanism, to form hydroperoxides, the primary oxidation products (Simic \& Taylor, 1987).

As one of the problems to consider when adding oil rich in PUFAs to the modified formulation of meat products is the high susceptibility of these fatty acids to oxidation, mainly if the products will be heated or cooked, it is very important to utilize antioxidants to control rancidity development.

The MRPs concentrations tested were chosen based on results obtained from previous studies (Fernández, Romero, Doval, Sturla, \& Judis, 2010), which reported that an optimum MRP concentration with antioxidant effect on oil/water emulsion was 3\%, while higher amounts of MRPs exerted a pro-oxidant effect.

To study this behaviour in the enriched meat products, a test with $0.5 \% ; 1 \% ; 3 \%$ and $5 \%$ MRP was carried out. The inhibitory effect of this additive on hydroperoxide formation in cooked modified beef patties was remarkable, and no pro-oxidant effect was observed (Figure 4).

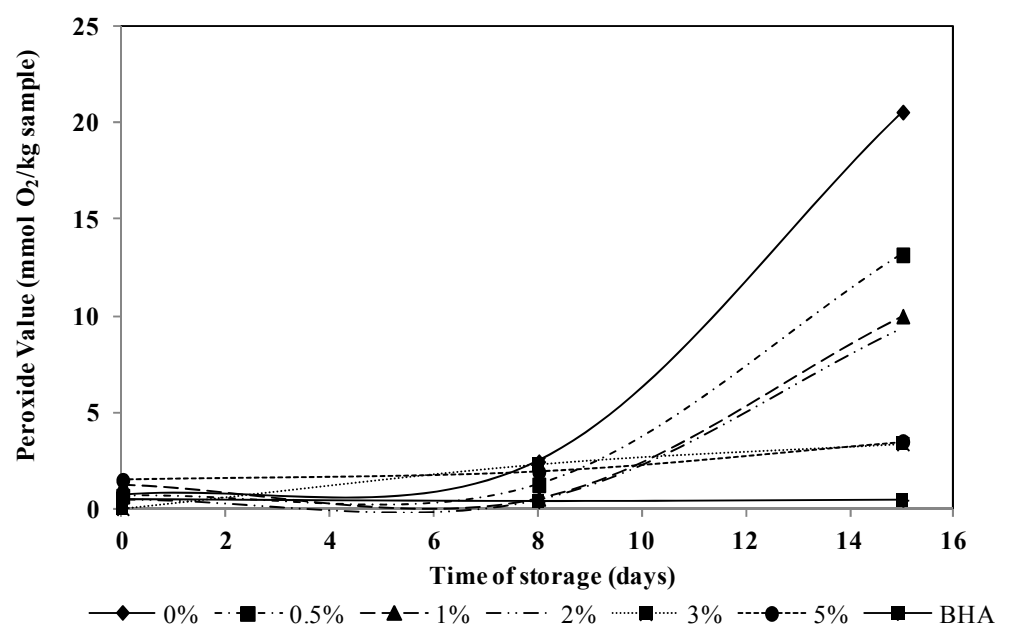

Figure 4. Effect of different MRP concentrations and BHA on Peroxide value in meat samples

The PV value of samples without antioxidant after 15 days of storage reached $20.55 \mathrm{mmol} \mathrm{O}_{2} / \mathrm{kg}$ sample, and when the $3 \%$ MRPs concentration was used, the peroxide level decreased to $3.51 \mathrm{mmol} \mathrm{O}_{2} / \mathrm{kg}$ sample. The synthetic antioxidant used as control $(0.01 \%$ BHA) completely inhibited PV formation.

At the end of storage, the reduction percents of peroxidation on hydroperoxide formation were $36 \%, 51 \%, 54 \%$, $83 \%$ and $83 \%$ at MRP concentrations of $0.5 \%, 1 \%, 2 \%, 3 \%$ and $5 \%$ respectively. BHA $(0.01 \%)$ exerted a $96 \%$ peroxidation reduction (Figure 5). 


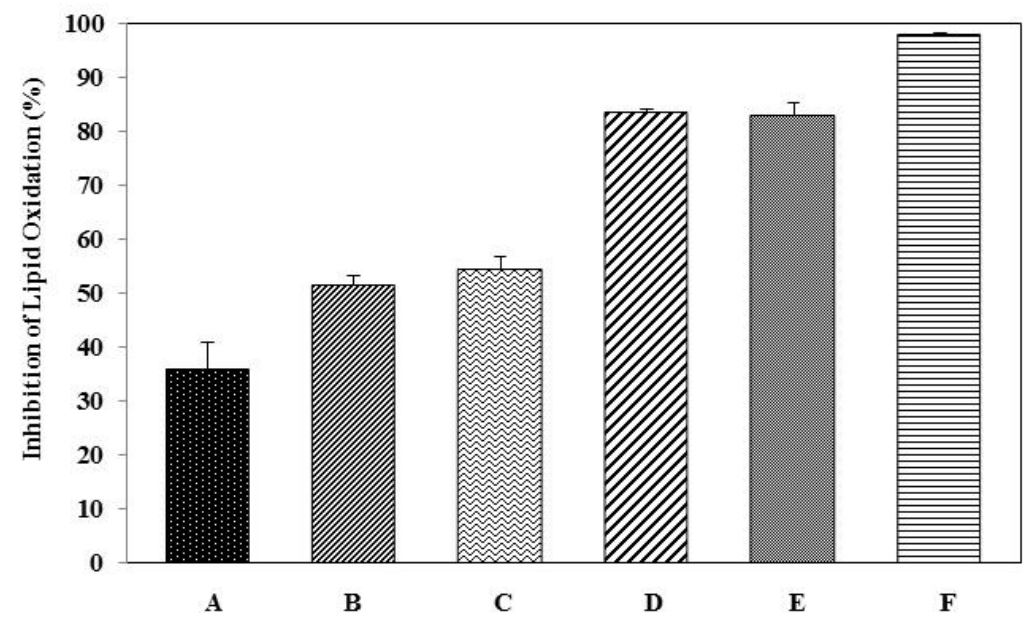

Figure 5. Inhibition percent of lipid oxidation by different MRP concentrations and BHA on hydroperoxide formation (A: $0.5 \%$ MRP; B: 1 \% MRP; C: $2 \%$ MRP; D: $3 \%$ MRP; E: $5 \%$ MRP and F: $0.01 \%$ BHA)

The results confirm the ability of MRPs to act as an efficient inhibitor of lipid peroxidation in muscle food products. This agrees with Chaijan, Kewmanee, Hirunkan, Aryamuang and Panpipat (2009) who reported that the oxidation of refrigerated mackerel fillets was prevented by the addition of mackerel sarcoplasmic proteins and galactose MRPs, obtaining a 12\% reduction of hydroperoxide formation. Furthermore, Dong et al. (2012) informed that MRPs from hydrolyzed $\beta$-lactoglobulin-glucose with a 4-hour heating time also exhibited an antioxidative activity (RP $59 \%$ ) in fish oil/water emulsion.

As far as lipid peroxidation is concerned, free radicals abstract hydrogen from a fatty acid double bond to produce fatty acid free radicals, which further react with oxygen to produce fatty acid hydroperoxide. The hydroperoxide is unstable and decomposes readily to volatile compounds such as aldehydes; the primary products can be measured as peroxide value (PV) and secondary products can be determined as thiobarbituric acid reactive substances (TBARS).

Data of the TBARs formation in enriched cooked beef patties with similar MRPs and synthetic BHA are presented in Figure 6.

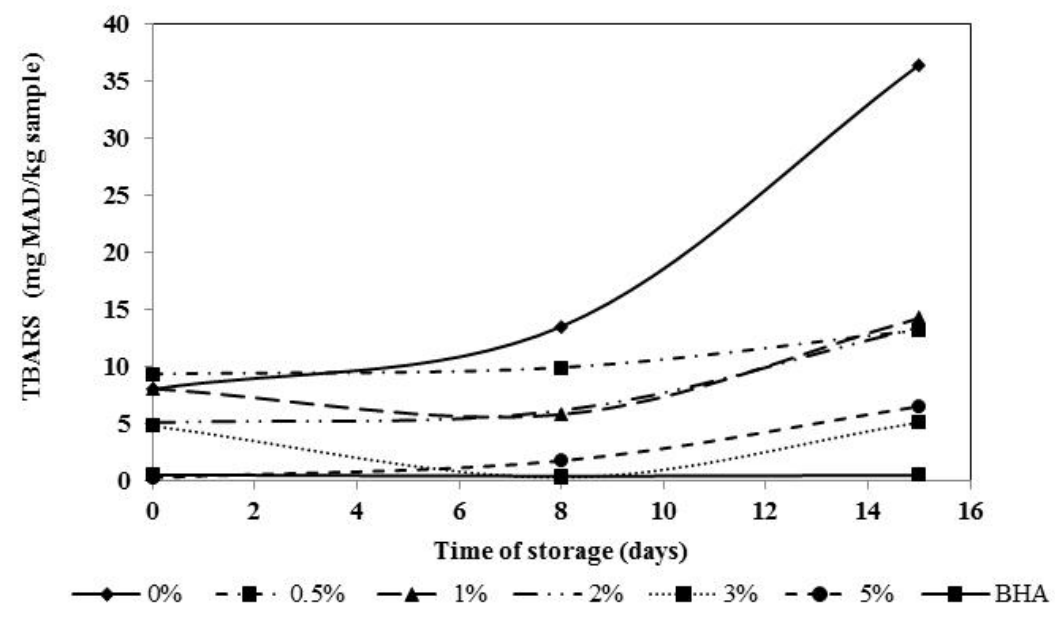

Figure 6. Effect of different MRP concentrations and BHA on TBARS formation in meat samples

All concentrations of MRPs assayed inhibited the TBARs formation during storage. Compared to untreated sample at the end of storage, the more efficient concentration was $3 \%$, reducing the production of TBARs by $85 \%$. The synthetic antioxidant exerted a $98 \%$ reduction (Figure 7). 


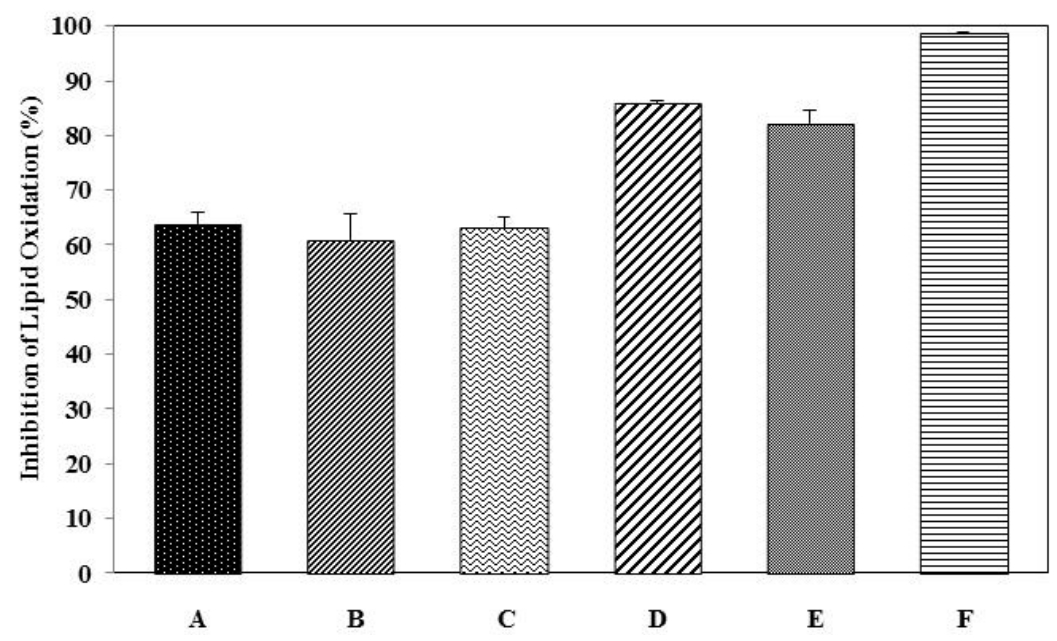

Figure 7. Inhibition percent of lipid oxidation by different MRP concentrations and BHA on TBARS formation (A: $0.5 \%$ MRP; B: 1 \% MRP; C: $2 \%$ MRP; D: 3 \% MRP; E: 5 \% MRP and F: $0.01 \%$ BHA)

These results are higher than those informed by Miranda and Rakovsky (2012) who reported that MRPs obtained from Valine-Glucose added to ground chicken breast decreased a $61 \%$ of the TBAR formation in refrigerated storage when $0.1 \mathrm{mg} / \mathrm{g}$ of MRP was added.

Then, the strong suppression of lipid oxidation (both PV and TBARs) by MRPs from sarcoplasmic proteins/MAD in cooked beef patties could be due to mechanisms related to a higher reduction power and a major iron-protein interaction. This is because amino acid residues such as histidine, glutamic acid, aspartic acid, phosphorylated serine and threonine from sarcoplasmic protein, capable to chelate metals, were exposed on the protein surface during the MRP formation process (Elias, Kellerby, \& Decker, 2008).

\section{Conclusions}

The MRPs obtained from sarcoplasmic proteins/MAD presented a high reducing power, a low phenolic compounds content, and a minor DPPH and $\mathrm{ABTS}^{+}$radicals scavenging activity.

As far as oxidative stability of the enriched n3 PUFA beef patties concerns, all concentrations assayed showed an antioxidative effect on hydroperoxide and thiobarbituric acid reactive substances formation, being $3 \%$ of MRPs the more efficient.

As MRPs are complex compounds and could act simultaneously with different mechanisms of action, further studies on the formation process and structure identification of active compounds in Maillard reaction are needed.

\section{References}

Ajandouz, E., Desseaux, V., Tazi, S., \& Puigserver, A. (2008). Effects of temperature and pH on the kinetics of caramelisation, protein cross-linking and Maillard reactions in aqueous model systems. Food Chemistry, 107(3), 1244-1252. http://dx.doi.org/10.1111/j.1365-2621.2001.tb08213.x

Asakura, T., Nakamura, Y., Inou, N., Murata, M., \& Homma, S. (1990). Characterization of zinc chelating compounds in instant coffe. Agricultural and Biological Chemistry, 54, 855-862. http://dx.doi.org/10.1271/bbb1961.54.855

Bedinghans, A., \& Ockerman, H. (1995). Antioxidative Maillard reaction products from reducing sugars and free amino acids in cooked ground pork patties. Journal of Food Science, 60, 992-995. http://dx.doi.org/10.1111/j.1365-2621.1995.tb06277.x

Benjakul, S., Lertittikul, W., \& Bauer, F. (2005). Antioxidant activity of Maillard reaction products from a porcine plasma protein-sugar model system. Food Chemistry, 93, 189-196. http://dx.doi.org/10.1016/j.foodchem.2004.10.019

Bligh, E., \& Dyer, W. (1959). A rapid method of total lipid extraction and purification. Canadian Journal of Biochemistry and Physiology, 37, 911-917. http://dx.doi.org/10.1139/059-099

Chaijan, M., Kewmanee, D., Hirunkan, F., Aryamuang, S., \& Panpipat, W. (2009). Oxidative stability of 
refrigerated mackerel fillet as influenced by Maillard reaction products. Asian Journal of Food and Agro-Industry, 2(04), 917-931. $\quad$ Retrieved from http://www.ajofai.info/Abstract/Oxidative $\% 20$ stability $\% 20 \mathrm{of} \% 20$ refrigerated $\% 20$ mackerel $\% 20$ fillets $\% 20$ as \%20influenced\%20by\%20maillard\%20reaction\%20products.pdf

Dean, R., Hunt, J., Grant, A., Yamamoto, Y., \& Niki, E. (1991). Free radical damage to proteins: the influence of relative delocalization of radical generation, antioxidants and target proteins. Free Radical Biology and medicine, 11, 161-168. http://dx.doi.org/10.1016/0891-5849(91)90167-2

Decker, E. A., \& Shanta, N. C. (1994). Concentration of the anticarcinogen, conjugated linoleic acid in beef. Meat Focus International, 3, 61-62

Dong, S., Panya, A., Zeng, M., Chen, B., Mc Clements, J., \& Decker, E. (2012). Charcateristics and antioxidant activity of hydrolyzed $\beta$-lactoglobulin-glucose Maillard reaction products. Food Research International, 46, 55-61. http://dx.doi.org/10.1016/j.foodres.2011.11.022

Elias, R., Kellerby, S., \& Decker, E. (2008). Antioxidant Activity of Proteins and Peptides. Critical Reviews in Food Science and Nutrition, 48(5), 430-441. http://dx.doi.org/10.1080/10408390701425615

Elmore, J., Mottram, D., Enser, M. \& Wood, J. (1999). Effect of the Polyunsaturated Fatty Acid Composition of Beef Muscle on the Profile of Aroma Volatiles. Journal of Agricultural and Food Chemistry, 47, 1619-1625. http://dx.doi.org/ 10.1021/jf980718m

Eweedah, N., Rozsa, L, Gundel, J., \& Varlegyi, J. (1997). Comparison of fullfat soybean, sunflower seed and protected fat as fat supplements for their effect on the performance of growing-finishing bulls and carcass fatty acid composition. Acta Veterinaria Hungarica, 45(2), 151-163. Retrieved from http://www.ncbi.nlm.nih.gov/pubmed/9270138

Fernández, C., Romero, A., Doval, M., Sturla, M., \& Judis, M. (2010). Influence of meat components on antioxidant activity of beef sarcoplasmic proteins/malondialdehyde reaction products in model emulsions. Electronic Journal of Environmental, Agricultural and Food Chemistry, 9(3), 636-645.

Gandemer, G. (1999). Lipids and meat quality: lipolysis, oxidation, maillard reacts and flavour. Sciences-des-Aliments, 19, 439-458.

Gomyo, T., \& Hirokoshi, M. (1976). On the interaction of melanoidins with metal ions. Agricultural and Biological Chemistry, 40, 33-40. http://dx.doi.org/10.1271/bbb1961.40.33

Gu, F., Kim, J., Hayat, K., Xia, S., Feng, B., \& Zhang, X. (2009). Characteristics and antioxidant activity of ultrafiltrated Maillard reaction products from a casein-glucose mmodel system. Food Chemistry, 117, 48-54. http://dx.doi.org/10.1016/j.foodchem.2009.03.074

Hoogenkamp, H. (1997). Formulated meat patties-global taste preference changes. Fleischwirtschaft, 77(10), 906-912.

Jacobsen, C., Hartvigsen, K., Lund, P., Thomsen, M., Skibsted, L., \& Holmer, G. (2001). Oxidation in fish oil-enriched mayonnaise: Effect of tocopherol concentration on oxidative deterioration. European Food Research Technology, 212, 308-318. http://dx.doi.org/ 10.1007/s002170000251

Jafar, S., Hultin, H., Bombo, A., Crowther, J., \& Barlow, S. (1994). Stabilization by antioxidants of mayonnaise made from Fish oil. Journal of Food Lipids, 1, 295-311. http://dx.doi.org/10.1111/j.1745-4522.1994.tb00254.x

Jayathilakan, H., Vasundhara, T., \& Kumudavally, K. (1997). Effect of spices and Maillard reaction products on rancidity development in precooked refrigerated meat. Journal of Food Science and Technology, 34, 128-131. Retrieved from http://cat.inist.fr/?aModele $=$ afficheN\&cpsidt $=2682678$

Jing, H., \& Kitts, D. (2002). Chemical and biochemical properties of casein - sugar Maillard reaction products. Food and Chemical Toxicology, 40, 1007-1015. http://dx.doi.org/10.1016/S0278-6915(02)00070-4

Johnson, R., Metcalf, P., \& Baker, J. (1983). Fructosamine: a new approach to the estimation of serum glycosylprotein. An index of diabetic control. Clinical Chemistry Acta, 127, 87-95. http://dx.doi.org/10.1016/0009-8981(83)90078-5

Kakuda, Y., Stanley, D., \& Van de Voort, F. (1981). Determination of TBA number by high performance liquid chromatography. Journal of American Oil Chemistry Society, 58, 773-775. http://dx.doi.org/10.1007/BF02887320 
Kalogeropoulos, N., Yannakopoulou, K., Gioxari, A., Chiou, A., \& Makris, D. (2010). Polyphenol characterization and encapsulation in b-cyclodextrin of a flavonoid-rich Hypericum perforatum (St John's wort) extract. Food Science and Technology, 43, 882-889. http://dx.doi.org/10.1016/j.lwt.2010.01.016

Ladikos, D., \& Lougovois, V. (1990). Lipid oxidation in muscle foods: A review. Food Chemistry, 35, 295-314. http://dx.doi.org/10.1016/0308-8146(90)90019-Z

Lingnert, H., \& Eriksson, C. E. (1981). Antioxidant effect of Maillard Reaction Products. Progress in Food \& Nutrition Science, 5, 453-466.

Maydata, A. (2002). Café, antioxidantes y protección a la salud. Medisan, 6(4), 72-81. Retrieved from http://www.bvs.sld.cu/revistas/san/vol7_4_02/san11402.htm

Miranda, L., Rakovsky, C., \& Were, L. (2012). Effect of Maillard reaction products on oxidation products in ground chicken breast. Meat Science, 90, 352-360. http://dx.doi.org/10.1016/j.meatsci.2011.07.022

Mottram, D. S. (1991). Meat. In Henk Maarse (Ed.). Meat in volatile compounds in foods and beverages, pp. 107-177. New York: Marcel Decker, Inc.

Naveena, B., Sen, A., Kingsly, R., Singh, D., \& Kondaiah, N. (2008). Antioxidant activity of pomegranate rind powder extract in cooked chicken patties. International Journal of Food Science and Technology, 43, 1807-1812. http://dx.doi.org/ 10.1111/j.1365-2621.2007.01708.x

Oyaizu, M. (1986). Studies on products of browning reactions: Antioxidative activities of product of browing reaction prepared from glucosamine. Japan Journal of Nutrition, 44, 307-315. http://dx.doi.org/10.5264/eiyogakuzashi.44.307

Pearson, A., \& Gray, J. (1983). Mechanism responsible for warmed over- flavour in cooked meat. In Waller, G.R., \& Feather, M.S. (Eds.), The Maillard reactionin Foods and Nutrition, pp. 287-300. American Chemistry Society Symposium Series. 215 Washington, DC. http://dx.doi.org/10.1021/bk-1983-0215.ch013

Re, R., Pellegrini, N., Proteggente, A., Pannala, A., Ming, Y., \& Rice-Evans, C. (1999). Antioxidant activity applying an improved ABTS radical cation decolorization assay. Free Radical Biology \& Medicine, 26, 1231-1237. http://dx.doi.org/10.1016/S0891-5849(98)00315-3

Rendleman, J. A. (1987). Complexation of calcium by melanoidin and its role in determinating bioavailability. Journal of Food Science, 52, 1699-1705. http://dx.doi.org/10.1111/j.1365-2621.1987.tb05909.x

Rival, S., Boeriu, C., \& Wichers, H. (2001). Caseins and Casein Hydrolysates. Antioxidative Properties and Relevance to Lipoxygenase Inhibition. Journal of Agricultural and Food Chemistry, 49, 295-302. http://dx.doi.org/ 10.1021/jf0003911

Robson, R., Goll, D., \& Temple, M. (1968). Determination of protein in Tris buffer by the Biuret reaction. Biochemical Analysis, 24, 339-341. http://dx.doi.org/10.1016/0003-2697(68)90188-7

Romero, A., Doval, M., Sturla, M., \& Judis, M. (2010). Antioxidative Effect of Fermented Soybeans Extract in Beef Patties with and without n-3 Fatty Acids. Journal of Life Sciences, 4, 12-16. Retrieved from http://perpustakaan.uns.ac.id/jurnal/upload_file/113-fullteks.pdf\#page $=15$

Simic, M., \& Taylor, K. (1987). Free radical mechanisms of oxidation reactions. In A. J. St. Angelo \& M. E. Bailey, (Eds.), Warmed - Over Flavor of Meat, pp. 69-72. Academic Press. New York.

Sinnhuber, R. O., \& Yu, T. C. (1977). The 2-thiobarbituric acid reaction. An objective measure of the oxidative determinating occurring in fats and oils. Journal of Japan Society of Fish Science, 26, 259-267.

Sun, Y., Hayakawa, S., Chuamanochan, M., Fujimoto M., Innun, A., \& Izumori. (2006). Antioxidant Effects of Maillard Reaction Products Obtained from Ovalbumin and Different D-Aldohexoses. Bioscience, Biotechnology and Biochemistry, 70(3), 598-605. http://dx.doi.org/10.1271/bbb.70.598

Terasawa, N., Murata, M., \& Homma, S. (1991). Separation of model melanoidin into components with copper chelating Sepharose 6B column chromatography and comparison of chelating activity. Agricultural and Biological Chemistry, 55(6), 1507-1514. http://dx.doi.org/10.1271/bbb1961.55.1507

Vasavada, M., \& Cornforth, D. (2006). Evaluation of antioxidant effects of raisin paste in cooked ground beef, pork and chicken. Journal of Food Science, 71, 242-246 http://dx.doi.org/10.1111/j.1750-3841.2006.00026.x

Wagner, J., \& Añon, M. (1985). Effect of freezing rate on the denaturation of myofibrillar proteins. Journal of Food Technology, 20, 735-744. http://dx.doi.org/10.1111/j.1365-2621.1985.tb01971.x 